Jean Marc Bernard MD, Michel Pinaud MD, Marie France Ganansia MD, Hervé Chatelier MD, Rémi Souron MD, Joseph Letenneur MD

\title{
Systemic haemodynamic and metabolic effects of deliberate hypotension with isoflurane anaes- thesia or sodium nitro- prusside during total hip arthroplasty
}

Isofurane (ISO) was examined as an alternative hypotensive agent to nitroprusside (SNP) in 16 patients (mean age: 60 years) anacsthetized for total hip arthroplasty. MAP was decreased to 50 per cent of the awake level by infusion of SNP in Group I $(n=8)$ and with ISO in Group $I(n=8)$. Fentanyl $\left(10-16 \mu \mathrm{g} \cdot \mathrm{kg}^{-1}\right)$ was administered to both groups. Haemodynamic measurements were repeated in the lateral position before, during and after hypotension. Polygeline and fresh frozen plasmo were infused throughout the study period in volumes sufficient to maintain pulmonary capillary wedge pressure in the 7-9 mmHg range. The MAP decrease was the same in both groups, as were perioperative blood replacement (mean $500 \mathrm{ml}$ ), and postoperative haematocrits. Total perioperative fiurd replacement was higher $(p<0.07)$ in Group I (mean $2500 \mathrm{ml}$ ) than in Group II (mean $1300 \mathrm{ml}$ ). Venous tone was more affected by SNP than by ISO. ISO decreased the systemic vascular resistance index and oxygen consumption ( $\mathrm{VO}_{2}$ ) with . out any change in $\mathrm{Cl}$ or in $\dot{Q}_{s} \dot{Q} t$, in contrast to SNP which increased $\mathrm{Cl}, \dot{\mathrm{VO}} \mathrm{O}_{2}$ and $\dot{\mathrm{Q}}_{\mathrm{S}} \dot{\mathrm{Q}} \mathrm{r}$

\section{Key words}

ANAESTHETIC TECHNIQUES: induced hypotension, nitroprusside; ANAESTHETICS: VOLATILE, isoflurane; SURGERY: orthopaedics.

From the Département d'Anesthésiologie and Clinique Traumatologique (J.L.), Centre Hospitalięr Universitaire, Hỏtel-Dieu, Nantes, France.

Address correspondence to: Docteur M. Pinaud, Département d'Anesthésiologie, C.H.U. - Hôtel-Dieu, 44035 Nantes Cedex 01 France.

This work was supported in part by the University of Nantes Institutional Grants Program.
During total hip arthroplasty, blood loss can be decreased by employing hypotension. 1.2 The choice of the hypotensive agent remains controversial. Sodium nitroprusside (SNP) is the pharmacological agent of reference. ${ }^{3}$ Its side effects: (i) potential toxicity, ${ }^{4}$ (ii) rebound hypertension during withdrawal, ${ }^{5}$ (iii) reflex increase of the sympathetic ${ }^{6}$ and renin-angiotensin activity, ${ }^{7}$ and (iv) impairment of pulmonary gas exchange, ${ }^{8}$ encourage research on other controlled hypotension protocols.

Fluorinated volatile anaesthetic agents may provide a useful alternative. ${ }^{9}$ The mechanism underlying the decrcase in arterial pressure is different with each agent: depression of myocardial contractility is important with halothane and enflurane. The decrease in systemic vascular resistance is important with isoflurane, moderate with enflurane and only minimal with halothane ${ }^{10}$ Although depressed myocardial contractility has been shown with isoflurane in vitro,,$^{1-13}$ in vivo studies have not shown a decrease in cardiac output. ${ }^{14-17}$ While there are reports of the use of isoflurane-induced hypotension ${ }^{18-20}$ there are few clinical comparisons with SNP. ${ }^{21}$

The purpose of this study was to evaluate the haemodynamic and metabolic effects of isoflurane during hypotensive anaesthesia for total hip arthroplasty, compared with a technique using SNP.

\section{Methods}

The study was approved by the Committee on Ethics of our University Hospital. After giving their informed consent, 16 patients (ten wornen, six men) underwent total hip arthroplasty (Charnley Kerboull hip prosthesis) under general anaesthesia with similar surgical conditions. The medullary cavity was plugged by a plastic plug. A plastic catheter was used to vent blood, air and fat. The cement (orthopaedic bone cement powder type I CMW Labora- 
tories) was forced into the medullary cavity of the femur using the pulp of a thumb as a piston, 3-4 min after adding the liquid to the powder. The prosthesis was pushed into the cement and forced down.

Mean age was 60 (range 41-77). Six patients had a history of moderate essential hypertension either treated (alpha-methyldopa: five, thiazide diuretic: three) or untreated. Patients with ischaemic cerebral vascular disease, ischaemic myocardial disease or severe systemic hypertension were excluded from the study.

Heart rate was monitored by a $V_{S}$ ECG lead. An indwelling teflon cannula was inserted into a radial artery for systolic (SAP) and diastolic blood pressure (DAP) measurement. A 7-F triple lumen thermodilution catheter was inserted via the right internal jugular vein to measure the right atrial pressure (RAP), systolic (SPAP), and diastolic (DPAP) pulmonary arterial pressures, pulmonary capillary wedge pressure (PCWP) and cardiac output (CO) (iced injectate in triplicate). HR and pressures were recorded simultaneously on a polygraph (Mingograf 803 Siemens Elema). $\mathrm{PO}_{2}, \mathrm{PCO}_{2}, \mathrm{pH},(\mathrm{ABL} 30$ Acid-base analyzer, Radiometer), $\mathrm{SO}_{2}$ and haemoglobin concentration (OSM2 Hemoximeter, Radiometer) were measured in arterial blood and in mixed venous blood. Derived values: mean arterial pressure: MAP, cardiac index: CI, stroke index: SI, systemic vascular resistance index: SVRI, pulmonary vascular resistance index: PVRI, oxygen content, oxygen consumption $\left(\mathrm{V}_{2}\right)$, and intrapulmonary shunt ( $\dot{Q} s / \dot{Q} t)$ were computed according to standard formulae. ${ }^{22}$

\section{Protocol}

The patients were randomly assigned to one of two groups.

\section{GROUP I SNP-FENTANYL}

After premedication (diazepam $15 \mathrm{mg} P O$ ) anaesthesia was induced with thiopentone $\left(5 \mathrm{mg} \cdot \mathrm{kg}^{-1}\right)$, fentanyl $\left(5 \mu \mathrm{g} \cdot \mathrm{kg}^{-1}\right)$ and pancuronium $(0.1 \mathrm{mg} \cdot \mathrm{kg})$. After tracheal intubation, the patients were mechanically ventilated using a non-rebreathing circuit and IPPV. They received an $\mathrm{O}_{2} / \mathrm{N}_{2} \mathrm{O}$ mixture with $\mathrm{F}_{1} \mathrm{O}_{2}$ of 0.5 . End tidal $\mathrm{CO}_{2}$ was monitored with a capnometer (Hewlett Packard $47210 \mathrm{~A}$ ) and initial settings were modified in order to maintain $\mathrm{PaCO}_{2}$ between 4.2 and $5.2 \mathrm{kPa}(32-40 \mathrm{mmHg})$, with a respiratory rate of $16 /$ minute and an $1 / E$ ratio of 1/2. Supplementary doses of fentanyl and pancuronium were given during the operation. SNP was infused (concentration $200 \mathrm{mg}^{-\mathrm{L}^{-1}}$ ) through a teflon antecubital cannula used only for this purpose. Infusion was started with the skin incision, regulated from $1-6 \mu \mathrm{g} \cdot \mathrm{kg}^{-1} \cdot \mathrm{min}^{-1}$ to achieve the desired hypotension, and discontinued five minutes after placement of the second bone cement.

GROUP II ISOFLURANE-FENTANYL

The protocol was identical except that the SNP was replaced by isoflurane. Isoflurane four per cent (vaporizer setting, Isoflurane Vapor 19.3 Drager) was started before the skin incision, then the concentration was quickly decreased and modified in response to blood pressure. Isoflurane was discontinued five minutes after placement of the second bone cement. The isoflurane end-tidal concentration was monitored by a Normac Datex analyzer.

Arterial blood pressure was measured prior to general anaesthesia in order to determine the desired level of hypotension. The aim was to reach a moderate level of hypotension, equal to 50 per cent of the MAP of the awake patient, without going below $50 \mathrm{mmHg}$. Haemodynamic data and blood samples were collected during stable anaesthesia with the patients in the lateral position, before hypotension, during hypotension ( $15 \mathrm{~min}$ after the onset of hypotension, $5 \mathrm{~min}$ before the first cement, $5 \mathrm{~min}$ after the second cement), and after hypotension during skin closure (mean $\mathbf{4 0}$ min after insertion of the second cement). Fluid replacement was with colboids (polygeline) and fresh frozen plasma (FFP), in order to maintain PCWP between 7 and $9 \mathrm{mmHg}$. The goal was to maintain a constant ventricular preload in both groups to avoid deleterious consequences of a substantial degree of venodilation. Blood replacement (red blood cells) was done when blood loss exceeded $300 \mathrm{ml}$. Operative blood loss was assessed during the operation by weighing sponges, measuring suction drainage and estimating the amount of blood in the area of the wound, and after the operation by measuring blood collected from the wound drainage.

Results are expressed as mean $\pm \mathrm{SD}$. Intragroup comparisons over time were determined by analysis of variance for repeated measures, followed when indicated, by paired $\mathbf{t}$-test with Bonferroni corrections. Intergroup comparisons were made by analysis of variance where the two factors were treatment (SNP-fentanyl or isofuranefentanyl) and time (before, during and after hypotension). When variance was significant a modified Student's $t$ test was used to locate the difference. Significance was assumed when $\mathrm{p}<0.05$.

\section{Results}

Summary data for the two groups are presented in Table I. There were no significant haemodynamic differences between the groups prior to general anaesthesia. There were no complications during or after the study. MAP changes during the study are shown in Table II. In both 
TABLE I Demographic information and haemodynamic data before anaesthesia (Mean \pm SD)

\begin{tabular}{|c|c|c|}
\hline & $\begin{array}{l}\text { Nitroprusside- } \\
\text { fentanyl } \\
(n=8)\end{array}$ & $\begin{array}{l}\text { Isoflurane- } \\
\text { fentanyl } \\
(n=8)\end{array}$ \\
\hline Age (years) & $62(48-77)$ & $57(41-75)$ \\
\hline Weight $(\mathrm{kg})$ & $63(50-85)$ & $60(45-82)$ \\
\hline $\operatorname{Sex}$ & $5 \mathrm{~F} ; 3 \mathrm{M}$ & $5 \mathrm{~F} ; 3 \mathrm{M}$ \\
\hline Essential hypertension & 3 & 3 \\
\hline HR (beats $\left.\cdot \min ^{-1}\right)$ & $76 \pm 9$ & $77 \pm 10$ \\
\hline PCWP $(\mathrm{mmHg})$ & $5.9 \pm 1.9$ & $6.2 \pm 2.4$ \\
\hline$C l\left(L \cdot \min ^{-1} \cdot m^{-2}\right)$ & $3.45 \pm 0.62$ & $3.39 \pm 0.55$ \\
\hline SI $(\mathrm{m}) \cdot$ beat $\left.^{-1} \cdot \mathrm{m}^{-2}\right)$ & $45.4 \pm 10.3$ & $44.1 \pm 11.2$ \\
\hline SVRI (dyn's $\left.\cdot \mathrm{cm}^{-5} \cdot \mathrm{m}^{-2}\right)$ & $2500 \pm 482$ & $2452 \pm 357$ \\
\hline Hypotension duration (min) & $90 \pm 18$ & $85 \pm 25$ \\
\hline \multicolumn{3}{|l|}{ Total fentanyl dose $\left(\mu \mathrm{g} \cdot \mathrm{kg}^{-1}\right)$} \\
\hline - at incision & $10.3 \pm 2.1$ & $9.6 \pm 1.8$ \\
\hline - before 1st cement & $17.1=3.1$ & $15.9 \pm 4.1$ \\
\hline \multicolumn{3}{|l|}{ Operative blood losses (ml) } \\
\hline - during operarion & $330 \pm 100$ & $310 \pm 100$ \\
\hline - after operation & $530=300$ & $510 \pm 260$ \\
\hline - total & $860=320$ & $820 \pm 280$ \\
\hline \multicolumn{3}{|l|}{ Total fluid replacement (ml) } \\
\hline - red blood cells & $550 \pm 400$ & $500 \pm 350$ \\
\hline - fresh frozen plasma & $700=100$ & $300 \pm 100^{*}$ \\
\hline - polygeline & $1250 \pm 400$ & $500 \pm 100^{*}$ \\
\hline
\end{tabular}

${ }^{*} \mathrm{p}<0.0 \mathrm{t}$ vs nitroprusside.

Abbreviations: HR, heart rate; PCWP, pulmonary capillary wedge pressure; CI, cardiac index; Sl, stroke indcx; SVRl, systcmic vasculat resistance index.

groups the same decrease in MAP was achieved from induction of anaesthesia and positioning of the patients in the lateral position. There were no differences between the groups during hypotension. The decrease in MAP had a similar effect in both groups on the operative blood loss (Table I). The postoperative haematocrits were respectively $36.1 \pm 1.9$ and $36.6 \pm 5.4$ (NS). Fluid replacement (colloids, FFP and red blood cells), how-

TABLE II Mean arterial pressure (Mean \pm SD)

\begin{tabular}{lcc}
\hline & $\begin{array}{l}\text { Nuroprusside- } \\
f e n t a n y i \\
(n=8)\end{array}$ & $\begin{array}{l}\text { Isofurane- } \\
\text { fentanyl } \\
(n=8)\end{array}$ \\
\hline Awake in the supine position & $113 \pm 15$ & $109 \pm 13$ \\
Anaesthetized in the lateral position & $82 \pm 11$ & $89 \pm 15$ \\
Hypotension + 15 min & $58 \pm 9 \dagger$ & $62 \pm 7 \dagger$ \\
Hypotension 5 min before 1st cement & $63 \pm 9^{*}$ & $53 \pm 4 \ddagger$ \\
Hypotension 5 min after 2nd cement & $72 \pm 16$ & $58 \pm 9 \dagger$ \\
Skin closure & $118 \pm 13^{\ddagger}$ & $87 \pm 118$ \\
\hline
\end{tabular}

Wishin group variations: vs anatsthetized in the lateral position: ${ }^{*} \mathrm{p}<$ $0.05 ; \mathrm{tp}<0.01 ; \neq \mathrm{p}<0.001$.

Berween group variations: $\$ \mathrm{p}<0.01$ vs nitroprusside.
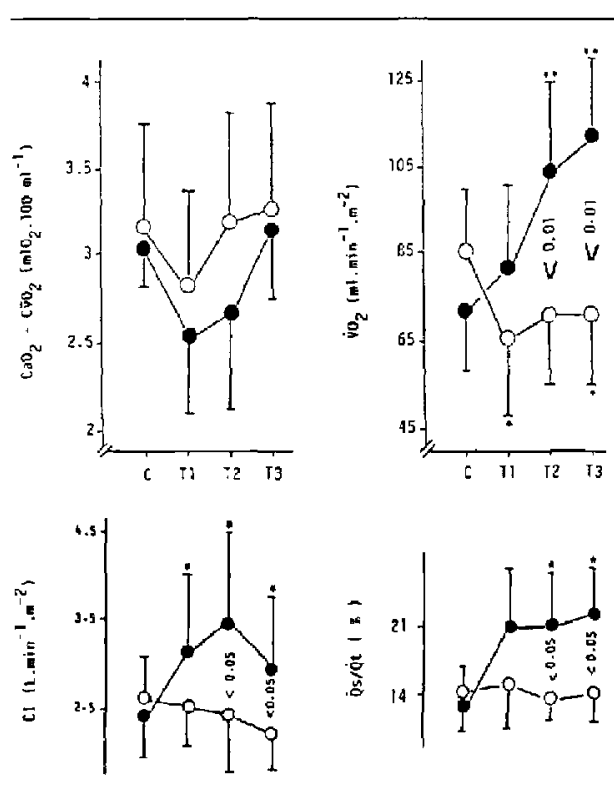

FIGURE Asterio-venous $\mathrm{O}_{2}$ difference $\left(\mathrm{CaO}_{2}-\mathrm{CvO}_{2}\right)$, oxygen consumption $\left(\mathrm{VO}_{2}\right)$, cardiac index $(\mathrm{Cl})$ and intrapulmonary shunt (Q $(\dot{Q} / \mathrm{Q} t)$ in Group 10 (nitroprusside-fentanyl) and in Group II O (isofluranefentanyl) in the lateral position beforc hypotension (C), and during hypotension 15 minutes after it was started (T1), 5 minutes before first cement (T2) and 5 minutes afier the second cement (T3). Mean value \pm SD; when compared with control values in the lateral position before hypotension (C): ${ }^{*} \mathrm{p}<0.05 ;{ }^{* *} \mathrm{p}<0.01$.

ever, was significantly more $(\mathrm{p}<0.01)$ in the SNPfentanyl group ( $2500 \pm 900 \mathrm{ml})$ as compared to the isoflurane-fentanyl group $(1300 \pm 500 \mathrm{ml})$. The isoflurane end-tidal maintenance concentration was $0.6 \pm 0.2$ vol\% and the total amount of isofurane needed was $0.37 \pm$ $0.14 \mathrm{ml} \cdot \mathrm{kg}^{-1} \cdot \mathrm{h}^{-1}$. Blood pressure started to rise immediately after the SNP infusion was stopped and rebound hypertension occurred, as compared to values with the patient in the lateral position before bypotension ( $\mathrm{p}<$ 0.01 ; Table I). Blood pressure started to rise 8 to $10 \mathrm{~min}$ after isoflurane was stopped, reaching its prehypotensive level without rebound.

\section{Within group variations}

The changes in haemodynamic and metabolic data during hypotension are shown in Table III and in the Figure. With SNP-fentanyl, SVRI $(\mathrm{p}<0.01)$ and $\mathrm{PaO}_{2}(\mathrm{p}<$ 0.05 ) were significantly decreased, $\mathrm{Cl}, \dot{\mathrm{Q} s} / \dot{\mathrm{Q}} \mathrm{t}(\mathrm{p}<0.05)$, and $\mathrm{VO}_{2}(\mathrm{p}<0.01)$ were significantly increased. With isoflurane SVRI $(p<0.01)$ and $\mathrm{VO}_{2}(p<0.05)$ were 
TABLE III Data summary during sodium nitroprusside-fentanyl hypotension (Group I) and isoflutane-ientanyl hypotersion (Group II) (Mean $\pm \mathrm{SD}$ )

\begin{tabular}{|c|c|c|c|c|c|c|}
\hline & Group & $\begin{array}{l}\text { Lateral } \\
\text { position }\end{array}$ & $\begin{array}{l}\text { Hypotension } \\
+15 \mathrm{~min}\end{array}$ & $\begin{array}{l}\text { Hypotension } \\
5 \text { min before } \\
\text { Ist cement }\end{array}$ & $\begin{array}{l}\text { Hypotension } \\
5 \text { min after } \\
\text { 2nd cement }\end{array}$ & Significance \\
\hline $\begin{array}{l}\text { HR } \\
\text { (beals'min }{ }^{-1} \text { ) }\end{array}$ & $\begin{array}{l}\text { SNP } \\
\text { ISO }\end{array}$ & $\begin{array}{l}70 \pm 9 \\
75 \pm 12\end{array}$ & $\begin{array}{l}73 \pm 10 \\
71 \pm 11\end{array}$ & $\begin{array}{l}81 \pm 18 \\
75 \pm 13\end{array}$ & $\begin{array}{l}75 \pm 15 \\
68 \pm 9\end{array}$ & $\begin{array}{l}\text { NS } \\
\text { NS }\end{array}$ \\
\hline $\begin{array}{l}\text { RAP } \\
(\mathrm{mmHg})\end{array}$ & $\begin{array}{l}\text { SNP } \\
\text { ISO }\end{array}$ & $\begin{array}{l}4.9 \pm 2.7 \\
3.5 \pm 2.6\end{array}$ & $\begin{array}{l}4.7 \pm 3.1 \\
4.2 \pm 3.6\end{array}$ & $\begin{array}{l}4.0 \pm 4.5 \\
3.7 \pm 2.7\end{array}$ & $\begin{array}{l}5.3 \pm 4.7 \\
4.4 \pm 2.3\end{array}$ & $\begin{array}{l}\text { NS } \\
\text { NS }\end{array}$ \\
\hline $\begin{array}{l}\text { MPAP } \\
(\mathrm{mmHg})\end{array}$ & $\begin{array}{l}\text { SNP } \\
\text { ISO }\end{array}$ & $\begin{array}{l}16.3=4.5 \\
14.1=2.9\end{array}$ & $\begin{array}{l}15.0 \pm 3.5 \\
13.5 \pm 2.6\end{array}$ & $\begin{array}{l}14.7 \pm 3.8 \\
13.2 \pm 2.5\end{array}$ & $\begin{array}{l}19.8 \pm 3.1 \pm \\
16.0 \pm 2.7\end{array}$ & $\begin{array}{l}\text { NS } \\
\text { NS }\end{array}$ \\
\hline $\begin{array}{l}\text { PCWP } \\
(\mathrm{m}: m \mathrm{Hg})\end{array}$ & $\begin{array}{l}\text { \$NP } \\
\text { ISO }\end{array}$ & $\begin{array}{l}8.5=3.0 \\
7.4 \pm 3.4\end{array}$ & $\begin{array}{l}8.0 \pm 4.6 \\
6.5 \pm 4.2\end{array}$ & $\begin{array}{l}8.1 \pm 3.6 \\
7.6 \pm 3.8\end{array}$ & $\begin{array}{l}8.9 \pm 4.3 \\
7.2 \pm 2.7\end{array}$ & $\begin{array}{l}\text { NS } \\
\text { NS }\end{array}$ \\
\hline $\begin{array}{l}\text { CI } \\
\left(L \cdot \min ^{-1} \cdot m^{-2}\right)\end{array}$ & $\begin{array}{l}\text { SNP } \\
\text { ISO }\end{array}$ & $\begin{array}{l}2.40 \pm 0.60 \\
2.59 \pm 0.49\end{array}$ & $\begin{array}{l}3.20 \pm 0.88^{*} \\
2.48 \pm 0.46\end{array}$ & $\begin{array}{l}3.42 \pm 1.18^{*} \div \\
2.37 \pm 0.76\end{array}$ & $\begin{array}{l}3.13 \pm 0.85 \ddagger \\
2.14 \pm 0.62\end{array}$ & $\begin{array}{l}<0.05 \\
\text { NS }\end{array}$ \\
\hline $\begin{array}{l}\text { SI } \\
\left(\mathrm{ml} \cdot \text { beat }^{-1} \cdot \mathrm{m}^{-2}\right)\end{array}$ & $\begin{array}{l}\text { SNP } \\
\text { ISO }\end{array}$ & $\begin{array}{l}34 \pm 7 \\
36 \pm 10\end{array}$ & $\begin{array}{l}44 \pm 9 \\
36 \pm 10\end{array}$ & $\begin{array}{l}42 \pm 18 \\
32 \pm 10\end{array}$ & $\begin{array}{l}42 \pm 12 \pm \\
31 \pm 6\end{array}$ & $\begin{array}{l}\text { NS } \\
\text { NS }\end{array}$ \\
\hline $\begin{array}{l}\text { SVRI } \\
\left(\mathrm{d} y n \cdot \mathrm{s} \cdot \mathrm{cm}^{-5} \cdot \mathrm{m}^{-2}\right)\end{array}$ & $\begin{array}{l}\text { SNP } \\
\text { ISO }\end{array}$ & $\begin{array}{l}2570 \pm 535 \\
2740 \pm 712\end{array}$ & $\begin{array}{l}1335 \pm 380^{\ddagger} \div \\
1911 \pm 354^{*}\end{array}$ & $\begin{array}{l}1380 \pm 465 * \ddagger \\
1850 \pm 505 \dagger\end{array}$ & $\begin{array}{l}1704 \pm 250^{*} \\
2132 \pm 633\end{array}$ & $\begin{array}{l}<0.01 \\
<0.01\end{array}$ \\
\hline $\begin{array}{l}\text { PVRI } \\
\left(\mathrm{dyn} \cdot \mathrm{s} \cdot \mathrm{cm}^{-5} \cdot \mathrm{m}^{-2}\right)\end{array}$ & $\begin{array}{l}\text { SNP } \\
\text { ISO }\end{array}$ & $\begin{array}{l}260 \pm 80 \\
218 \pm 61\end{array}$ & $\begin{array}{l}175 \pm 82 \\
213 \pm 88\end{array}$ & $\begin{array}{l}155 \pm 53 \\
188 \pm 32\end{array}$ & $\begin{array}{l}278 \pm 92 \\
325 \pm 93 t\end{array}$ & $\begin{array}{l}\text { NS } \\
<0.01\end{array}$ \\
\hline $\mathrm{pH}$ & $\begin{array}{l}\text { SNP } \\
\text { ISO }\end{array}$ & $\begin{array}{l}7.41 \pm 0.03 \\
7.40 \pm 0.04\end{array}$ & $\begin{array}{l}7.42 \pm 0.03 \\
7.41 \pm 0.04\end{array}$ & $\begin{array}{l}7.42 \pm 0.03 \\
7.40 \pm 0.03\end{array}$ & $\begin{array}{l}7.41 \pm 0.04 \\
7.39 \pm 0.04\end{array}$ & $\begin{array}{l}\text { NS } \\
\text { NS }\end{array}$ \\
\hline $\begin{array}{l}\mathrm{PaCO}_{2} \\
(\mathrm{kPa})\end{array}$ & $\begin{array}{l}\text { SNP } \\
\text { ISO }\end{array}$ & $\begin{array}{l}5.0 \pm 0.2 \\
5.0 \pm 0.2\end{array}$ & $\begin{array}{l}5.0 \pm 0.3 \\
4.8=0.3\end{array}$ & $\begin{array}{l}5.1 \pm 0.3 \\
4.9 \pm 0.3\end{array}$ & $\begin{array}{l}5.1 \pm 0.3 \\
4.9 \pm 0.3\end{array}$ & $\begin{array}{l}\text { NS } \\
\text { NS }\end{array}$ \\
\hline $\begin{array}{l}\mathrm{PaO}_{2} \\
(\mathrm{kPa})\end{array}$ & $\begin{array}{l}\text { SNP } \\
\text { ISO }\end{array}$ & $\begin{array}{l}24.5 \pm 4.5 \\
23.9 \pm 5.7\end{array}$ & $\begin{array}{l}20.1 \pm 4.5 \\
24.4 \pm 6.4\end{array}$ & $\begin{array}{l}17.9 \pm 4.3^{*} \neq \\
25.9 \pm 5.5\end{array}$ & $\begin{array}{l}18.9 \pm 4.8^{*} \ddagger \\
25.8 \pm 5.4\end{array}$ & $\begin{array}{l}<0.05 \\
\text { NS }\end{array}$ \\
\hline
\end{tabular}

Within group variations: ys lateral position *p<0.05; $\mathrm{t} p<0.01$.

Between group variations: vs Group II $\neq p<0.05$.

Abbreviations: See Table I RAP, right aưial pressure; MPAP, mean pulmonary artery pressure; PVRI, pulmonary vascular resistance index.

significantly decreased without any change in $\mathrm{CI}, \mathrm{Q} s / \mathrm{Q}$, $\mathrm{pH}, \mathrm{PaCO}_{2}$ and $\mathrm{PaO}_{2}$.

\section{Between group comparisons}

The two groups, which were haemodynamically identical before hypotension, behaved differently during hypotension: $\mathrm{Cl}, \mathrm{VO}_{2}$ and $\mathrm{QS} / \dot{\mathrm{Q}}$ were smaller in the isoflurane-fentanyl group before the first cement $(p<0.05)$ and after the second cement $(p<0.05)$; SVRI was higher in the isoflurane-fentanyl group 15 minutes after the hypotension onset $(p<0.05)$ and before the first cement $(p<0.05)$; SI was less in the isoflurane-fentanyl group after the second cement $\left(p<0.05\right.$ ); $\mathrm{PaO}_{2}$ was reduced in the SNP-fentanyl group before the first cement $(p<0.05)$ and after the second cement $(p<0.05)$.

\section{Discussion}

An attempt was made to control left ventricular filling pressures by infusing fluid to maintain PCWP. The haemodynamic response to the administration of SNP repre- sents a combination of venous pooling and reduced arterial impedance. ${ }^{23}$ In patients with a normal or nearly normal left ventricle the further decrease in PCWP during hypotension in the absence of fuid loading will have a more profound effect on cardiac output than the concomitant reduction of impedance leading to a fall in cardiac output. Furthermore, as suggested by Khambatta et al. ${ }^{8}$ the increase in pulmonary deadspace may be minimized by the maintenance of filling pressures and cardiac output. In the absence of such a fluid replacement protocol and controlled PCWP, the observed changes in cardiovascular function may have been different so that the results of our experiment are applicable only to the exact experimental circumstance we employed.

Isoflurane allowed us to reach quickly the desired level of hypotension. A maintenance inspired concentration of $1 \pm 0.2$ per cent (according to vaporizer setting) was enough to maintain the desired hypotension level if fentanyl doses were important $\left(10 \mu \mathrm{g} \cdot \mathrm{kg}^{-1}\right.$ on skin incision; $16 \mu \mathrm{g} \cdot \mathrm{kg}^{-1}$ on cement insertion). During painful times 
of surgery - e.g., osteotomy of the greater trochanter, bone drilling and cement insertion - increased anaesthetic concentrations $(0.5-1$ per cent) were necessary for a short period of time. The use of fentanyl did not alleviate the haemodynamic changes occurring with cement insertion (systemic and pulmonary vasoconstriction). After isoflurane was stopped there was no hypertensive rebound. Therefore isoflurane was as potent, precise and easy to control as was SNP for the induction of deliberate hypotension. Isoflurane provided stable and reproducible hypotension without the tachyphylaxis or rebound hypertension seen with SNP.

Hypotension with isoflurane was the result of systemic vasodilatation, mainly on the arterial side; in order to maintain PCWP between 7 and $9 \mathrm{mmHg}$, lluid replacement was more important in the SNP-fentanyl group. This can be explained by the different sites of action of isoflurane and SNP on the vascular bed: mostly arterial vasodilatation with isofiurane and both arterial and venous vasodilatation with SNP. With SNP, $\mathrm{CI}$ and $\mathrm{VO}_{2}$ increased, whereas with isoflurane, CI, SI and HR were stable and $\mathrm{VO}_{2}$ decreased when compared to prehypotension levels in the anaesthetized patients. These are arguments for the good tolerance of the cardiovascular system for isoflurane, with respect to cardiac output and tissue perfusion. Controlled depression of haemodynamics and with it reduced $\dot{\mathrm{VO}}_{2}$ was accomplished with isoflurane in contrast to SNP which led to unnecessary increases in $\mathrm{CI}$ and $\mathrm{VO}_{2}$. Furthermore, there was a lack of variation of pulmonary arterial pressures and pulmonary vascular resistance, as shown by Klide ${ }^{24}$ and Moffit et $a .^{23}$ Finally, the intrapulmonary shunt fraction remained unchanged, as reported by Nicholas and Lam, ${ }^{26}$ in contrast to what is seen with SNP.8.21

The same dose of fentanyl was administered to both groups and may explain the lack of baroreflex-mediated tachycardia, due to increased parasympathetic tone. With the same level of hypotension and with the same HR, isoflurane and fentanyl were associated with a smaller decrease in SVRI and a smaller CI than SNP and fentanyl. However, the fentanyl doses of $10-16 \mu \mathrm{g} \cdot \mathrm{kg}^{-1}$ may not be enough to eliminate awareness during surgical procedure in all patients recejving a 50 per cent $\mathrm{N}_{2} \mathrm{O}-\mathrm{O}_{2}$ mixture and to exclude sympathetic stimulation during painful stimuli. Thus sympathetic stimulation due to light anaesthesia and to pain may explain the higher $\mathrm{CI}$ in the SNP-fentanyl group than in the isoflurane-fentanyl group. The combined use of isoflurane and fentanyl appears to produce more myocardial depression than the combined use of SNP and fentanyl. On the other hand, although the haemodynamic and plasma catecholamine responses to surgical stimulation are unmodified when fentanyl is added at low doses of $2 \mu \mathrm{g} \cdot \mathrm{kg}^{-1},{ }^{27}$ perhaps our administration of $10-16 \mu \mathrm{g} \cdot \mathrm{kg}^{-1}$ of fentanyl blunted the hormonal stress response to surgery which can counteract the negative inotropic effect of isoflurane. This should be kept in mind especially when painful surgical stimuli occur, because the use of fentanyl may decrease or eliminate several reflex phenomena, which may explain the relative myocardial tolerance of isoturane. However, despite its depressant effect on pumping function, isoflurane may be useful as an alternative hypotensive agent to SNP for several reasons: safety margin in terms of cardiac output, absence of impaiment of pulmonary gas exchange, and decrease in whole body oxygen consumption. In addition isoflurane exhibits a brain protective effect, due to a decrease of cerebral metabolism. ${ }^{28,29}$

In summary, isoflurane is a good alternative to sodium nitroprusside. It is easy to use, efficient in producing a level of moderate hypotension and a decreased blood loss for total hip arthroplasty. The change in cardiac output is acceptable, despite a significant decrease in blood pressure. It is possible that the interaction with fentanyl $\left(10-16 \mu \mathrm{g} \cdot \mathrm{kg}^{-1}\right)$, impedes cardiac pump function adaptability during some painful surgical stimuli. The optimal nature and dose of the analgesic used with isoflurane, as well as the magnitude of the hormonal response to pain, have yet to be defined in order to find the best combination.

\section{Acknowledgements}

The authors are grateful to Abbott Laboratories for providing isoflurane. We also thank Hélène Loizeau who typed the manuscript, and Ms N. Clément, RN, Ms T. Lanot, RN, Ms A. Morinière, RN, and Mr Y. Trochu, $\mathrm{RN}$, for their technical assistance.

\section{References}

1 Thompson GE, Miller RD. Stevens WC. Murray WR. Hypotensive anesthesia for total hip arthroplasty. A study of blood loss and organ function (brain, heart, liver, and kidney). Anesthesiology 1978; 48: 91-6.

2 Barbier-Bohm G, Desmonts JM, Couderc E, Moulin D. Prokocimer $P$. Olivier $H$. Comparative effects of induced hypotension and norvolemic haemodilution on blood loss in total hip arthroplasty. Br J Anaesth 1980; 52: 1039-43.

3 Coln JN, Burke LP. Nitroprusside. Ann Intern Med 1979; 91: 752-7.

4 Tinker $J H$, Michenfelder $J D$. Sodium nitroprusside: pharmacology, toxicology and therapeutics. Anesthesiology 1976; 45: 340-54.

5 Khambatta HJ, Stone JG, Khan E. Hypertension during anesthesia on discontinuation of sodium nitroprusside induced hypotension. Anesthesiology 1979; 51: 127-30.

6 Zubrow AB, Daniel SS, Stark RI, Husain MK, James LS. Plasma renin, catecholamincs, and vasopressin during 
nitroprusside-induced hypotension in ewes. Aresthesiology 1983; 58: 245-9.

7 Miller ED Jr, Ackeriy JA, Vaughan ED Jr, Peach MI, Epstein $R M$. The renin-angiotensin system during controlled hypotension with sodium nitroprusside. Anesthesi. ology 1977; 47: 257-62.

8 Khambatta HJ, Stone JG, Matteo RS. Effect of sodium nitroprusside-induced hypotension on pulmonary deadspace. Br J Anaesth 1982; 54: 1197-9.

9 Lam AM. Induced hypotension. Can Anaesth Soc J 1984; 31: $\$ 56-\$ 62$.

10 Jones $R M$. Clinical comparison of inhalation anaesthetic agents. Br J Anaesth 1984; 56: S57-S62.

II Kemmotsu $O$, Hashimoto $Y$. Shimosato $S$. Inotropic effects of isoflurane on mechanics of contraction in isolated cat papillary muscles from normal and failing hearts. Anesthesiology $1973 ; 39: 470-7$.

12 Fragaeus $L$, Christian $C$, Vantrigt $P$ et al. Inotropic effects of isoflurane on the hypertrophied left ventricle in dogs. Anesthesiology 1982; 57: A14.

13 Freedman B, Christian C, Hamm D, Everson C, Wechsler $A$. Isoflurane and myocardial protection. Anesthesiology 1983; 59: A25.

14 Graves CL. Macdermotr RW, Bidwai A. Cardiovascular effect of isoflurane in surgical patients. Anesthesiology 1974; 41: 486-9.

15 Tarnow J, Bruckner JB, Eberlein HJ, Hess W, Patschke D. Haemodynamics and myocardial oxygen consumption during isoflurane (Forane) anaesthesia in geriatric patients. Br J Anaesth 1976; 48: 669-75.

16 Shimosato $S$, Carter JG, Kemmotsu O, Tukahashi $T$. Cardiocirculatory effects of prolonged administration of isoflurane in normocarbic human volunteers. Acta Anaesthesiol Scand 1982; 26: 27-30.

17 Bastard OG, Carter JG, Moyers IR, Bross BA. Circulatary effects of isoflurane in patients with ischemic heart disease: a comparison with halothane. Anesth Analg 1984; 63: 635-9.

$18 \mathrm{Lam}$ AM, Gelb AW. Cardiovascular effects of isofluraneinduced hypotension for cerebral aneurysm surgery. Anesth Analg 1983; 62: 742-8.

19 Bishay EG, Fukunaga AF, Echiverri E, Smalgalski G, Ito $\mathrm{H}$, Webb J. Cardiovascular effect of prolonged isoflurane induced hypotension. Anesth Analg 1984; 63: 187.

20 Fusciardi V, Guggiari M, Retamal O, Pertuiset B, Philippon $J$, Viars $P$. Clinical use of isaflurane as an hypotensive agent for controlled hypotension during cerebral aneurysm surgery. Anesthesiulogy 1985; 63: A106.

21 Makiabi M, Warner D, Boarini D. Sakoll M, Adolphson A. A comparison of nitroprusside, nitroglycerin and deep isoflurane anesthesia for induced hypotension. Anesthesiology 1985; 63: A403.
$22 \mathrm{Hug}$ CC Jr. Monitoring. Chap 13 In: Miller RD, (Ed) Anesthesia. Ed 2. New York: Churchill-Livingston Inc 1986; 4 II-63.

23 Cohn $J$, Franciosa $J A$. Vasodilator therapy of cardiac failure (first of two parts). N Engl J Med 1977; 297: 27-31.

24 Klide $\mathbf{A M}$. Cardiopulmonary effect of enflurane and isoflurane in the dog. Am J Vet Res 1976; 37: 127-31.

25 Moffit EA, Barker RA, Gienn JJ et al. Myocardial metabolism and hemodynamic responses with isoflurane anesthesia for coronary artery surgery. Anesth Analg 1984; 63: 252.

26 Nicholas JF, Lam AM. Isoflurane-induced hypotension does not cause impaiment in pulmonary gas exchange. Can Anaesth Soc J 1984; 31: 352-8.

27 Gelman S, Rivas J, Erdemir H, Proctor J Mackrell T. Hormonal and hemodynamic responses to surgery during different anesthetic techniques. Anesthesiology 1983; 59 : A351.

28 Longnecker DE, Seyde WC. Cerebral oxygen tension during deliberate hypotension with sodium nitroprusside, 2-Cl-adenosine or deep isoflurane anesthesia in rats. Anesthesiology 1984; 61: A366.

29 Newberg $L A$, Milde JH, Michenfelder JD. Systemic and cerebral effects of isoflurane-indueed hypotension in dogs. Anesthesiology 1984; 60: 541-6.

\section{Résumé}

Lisoflurane (ISO) a étê confronté au nitroprussiate de sodium (NPS) comme agent d'hypotertsion contrôlée chez 16 patients (age moyen 60 ans) endormis pour remplacement prothétique de hanche. La pression artérielle moyenne ( $P A M$ ) a été réduite a 50 pour cent de sa valeur chez le sujet Eveillé par perfusion de NPS dans le groupe $I(n=8)$ et par inhalation d'ISO dans te groupe $\|(n=8)$. Tous les patients ont reçu du fentanyl $\left(10-16 \mu \mathrm{g} \cdot \mathrm{kg}^{-1}\right)$. Les mesures hémodynamiques ont été réalisées en décubiztus latêral avamt, pendant et après hypotension. Une expansion volemique par gélatine et plasma frais congelé a été conduite pendant l'étude pour maintenir la pression capillaire pulmonaire enire 7 et $9 \mathrm{mmHg}$. La baisse de PAM a êté la même dans les deux groupes de même que les volumes sanguins transfusés $(500 \mathrm{mi}$ en moyenre pour la période périopératoire) et les hématocrites postopératoires. L'expansion valémique périopératoire globale a été plus élevée $(p<0.01)$ dans le groupe ( $2500 \mathrm{ml}$ en moyenne) que dans le groupe II ( $1300 \mathrm{ml}$ en moyenne). Le secteur capacitif a été plus touché par le NPS que par l'ISO. L'ISO a diminué les résistances vasculaires systémiques et la consommation d'oxygène ( $\left(\mathrm{VO}_{2}\right)$ sans modification de l'index cardiaque (IC) et du shumt intrapuimonaire $(\dot{Q} s / \dot{Q} t)$, contrairemeni au SNP qui a aurgmenté $/ C$, $\mathrm{VO}_{2}$ et $\dot{Q} s / \dot{Q} t$ 